\title{
The Role of Mediation on Work Practices and Employee Involvement
}

\author{
Nuzulul Fatimah ${ }^{1 *}$, Nauman Tahir ${ }^{2}$, Muhammad Ali Ahmad ${ }^{3}$, Amna Batool ${ }^{*}$, Arbab Gul ${ }^{5}$, \\ Abid Fareed ${ }^{6}$
}

${ }^{1}$ High School of Economics Mahardhika, Surabaya, Indonesia

${ }^{2}$ Lahore Leads University, Pakistan

${ }^{3,6}$ Faculty of Economic and Business, Airlangga University, Indonesia

${ }^{4}$ Islamia University bahawalpur, Pakistan

${ }^{5}$ Quaid-i-Azam Islamabad University, Pakistan

1nuzulul.fatimah@stiemahardhika.ac.id, 2nuaman_khan@yahoo.com,

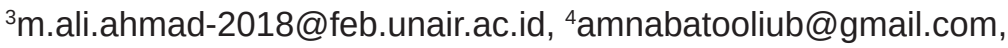

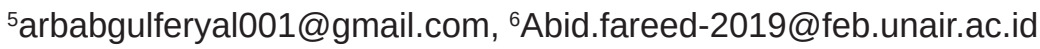

*Corresponding author

\begin{abstract}
Organizations face many challenges regarding employee engagement and employee job satisfaction. High engagement work practices (HIWP) must be implemented in order to have an impact on employee performance satisfaction. The purpose of this study was to examine the relationship between high-involvement work practices (HIWP) and job satisfaction with the mediating effect of employee engagement. Convenience sampling was used and data were collected through questionnaires from 185 organizational respondents. Regression analysis was used to test the hypothesis and Andrew F. Hayes model 4 was used to examine the mediating effect. The results showed that there was a significant relationship between the mediating variables and the effect of employee engagement. The practical implication of this research is to measure the level of job satisfaction of employees by using HIWP can be implemented for managers and employees.
\end{abstract} Keywords: high-involvement work practices, employee engagement, job satisfaction

\begin{abstract}
Abstrak
Organisasi menghadapi banyak tantangan terkait keterlibatan karyawan dan kepuasan kerja karyawan. HIWP harus diterapkan agar berdampak pada kepuasan kinerja karyawan. Tujuan penelitian ini untuk menguji hubungan antara praktik kerja keterlibatan tinggi (HIWP) dan kepuasan kerja dengan efek mediasi keterlibatan karyawan. Convenience sampling digunakan dan data dikumpulkan melalui kuesioner dari 185 responden. Analisis regresi digunakan untuk menguji hipotesis dan Andrew F. Hayes model 4 digunakan untuk memeriksa efek mediasi. Hasil penelitian menunjukkan bahwa ada hubungan yang signifikan antara variabel mediasi dengan pengaruh employee engagement. Implikasi praktis dari penelitian ini untuk menggukur tingkat kepuasan kerja pada karyawan dengan mengunakan HIWP bisa dilaksanakan bagi manajer dan karyawan.
\end{abstract}

Kata kunci: praktik kerja keterlibatan tinggi, keterlibatan karyawan, kepuasan kerja

\section{Cara Mengutip:}

Fatimah, N., Tahir, N., Ahmad, M. A., Batool, A., Gul, A., \& Fareed, A. (2021) The Role of Mediation on Work Practices and Employee Involvement. Esensi: Jurnal Bisnis dan Manajemen, Vol 11(2), 177-188. https://doi. org/10.15408/ess.v11i2.20389. 


\section{INTRODUCTION}

High engagement work is basically a set of applications used to improve employees' jobs by making their skills better, by motivating and sharing information with them and empowering them to achieve the best organizational performance which will further help to capture a competitive advantage (Ulum, 2012). These practices are carried out to increase the capacity of employee participation in the decision-making process also to increase employee's level of commitment to better organizational growth.

There are four HIWP attributes, namely power, information, appreciation and knowledge. Power is about participation in decision making, information sharing among employees, and rewards are about rewarding employees for good work done.Power means that organizations give their employees a sense of authority to engage in the process of decision-making to improve their productivity also to improve their work jobs (Tahir, 2013). This statement does not say that employees are given full or final authority and that they are not responsible for all of their decisions and results.

HIWP segment information refers to the authoritative mission, objectives, approach, methodology, changes, explanations for pressing organizational choices, organizational problems (BinBakr \& Ahmed, 2019). In addition to procuring information, including the number and nature of specializations. unit of yield, cost, revenue, profit, and level of consumer loyalty (Tahir, 2013). HIWP researchers states that representatives must be rewarded for their proper need for influence, data, and knowledge (Lowe Jr, 2021). rizes can be in the form of characteristics and outward appearances and can combine the strength of group motivation, profit sharing, share ownership, salary, advancement, recognition, and recognition (Emmywati et al., 2020). Lowe Jr (2021) argues that giving gifts to representatives can ensure that they are included and think about the conduct of the association.

Knowledge alludes to the talents and capacities of workers and is not exactly the same as data, which refers to the information representatives use to make choices or carry out activities (Ulum, 2012). Information is an important segment of HIWP because given the ultimate goal of completing a critical choice of work environment, it is the basis that representatives have the right items and capacity to measure options, talk about choices, and land on the right choices (Tahir, 2013).

Employee engagement is about employees having a positive attitude for the companyeither its principles (Rachmawati, 2014). When an employee gets well engaged, he or gives more attention to the company also motivated to work together to other employees for performance improvement. Job satisfaction is a pleasant emotional condition or position that results from appraising a person's work as an achievement and allowing one's work values to be realized. This stems from employees' perceptions of certain aspects of the job and the relationship between their expectations or needs and the perceptions they have while doing the job.

In today's environment, employee performance is very important for the progress and growth of an organization. Employee performance is influenced by many factors such as the work environment, monetary rewards, incentives and tasks assigned to employees to perform. If the tasks assigned to employees are in accordance with their interests and employees are involved in it with the proper implementation of HIWP then they will be satisfied and their performance will be good. In the banking sector in Pakistan, this issue is very valuable. 
Because in this sector, higher management does not focus on the implementation of HIWP. As a result, employees are not well engaged and dissatisfied with their work.

High involvement work practices are practices that need further investigation because these practices lead to employee engagement which in turn leads to job satisfaction. Organizations that focus on and drive HIWP including work-related power, information, knowledge and reward management, demonstrate, and maintain employee engagement to higher level. Organizational performance either employee welfare, which are aspects of employee engagement, increase employee satisfaction to higher level. In the current state, it is very important for organizations to be effective and efficient and for that, they have to achieve a higher level of employee engagement related to obtain employee satisfaction.

Organizations face many challenges dealing with employee engagement and employee work satisfaction. To increase employee job satisfaction into another level, HIWP must be implemented so that it gets an effect on employee job satisfaction. In aiming to examine the effect of HIWP on work satisfaction and how the role of HIWP through employee engagement that leads to work satisfaction.

According to above explanation, frame work in present studymay be presented in Figure 1. The thinking framework is an initial guideline in measuring the relationship between variables, so it must be described in the initial estimate as material for further analysis. Presentation of estimates in the form of research hypotheses.

Figure 1. Thinking Framework (Research Model)

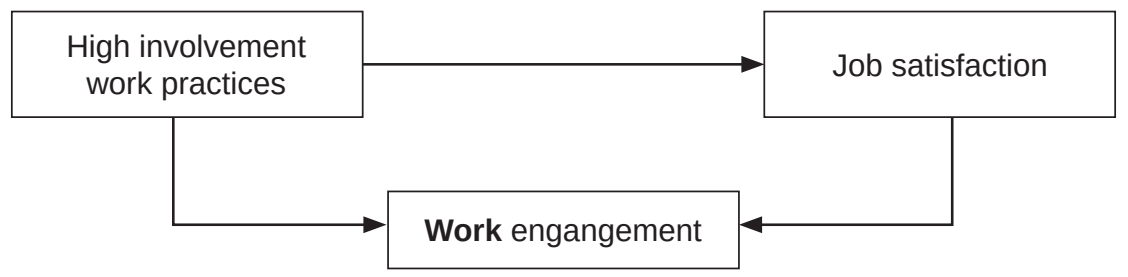

\section{METHOD}

Data collection methods in present research are documentation study, interviews and a list of questions (questionnaire). Whereas the empirical regression test as data analysis method on examining the impact of HIWP on job satisfaction, this study uses various statistical techniques, including regression, correlation analysis techniques and Andrew F, Hayes' model is used to test the mediation effect with model 4 . The regression test has explained about dependency dependence. The independent variable on the independent variable shows that how much change in the dependent variable may be caused by the independent variable. Correlation test is conducted to test whether the two variables are linearly connected to several populations. Correlation basically tells about the intensity (strong or weak) of the relationship between two variables and the direction of the relationship (positive or negative). Data analysis that helps to explain, display, or interpret data in a meaningful way is referred to as descriptive statistics. Therefore, descriptive statistics enable us to represent the information in a meaningful manner, allowing for easier analysis of the data. Descriptive statistics are basically used to check the normality of the data. 


\section{RESULT AND DISCUSSION}

The first column in Table 1 show the demographic section of this study shows the gender classification of the respondents including two types, male and female. In SPSS 1 is considered for men and 2 for women. Male respondents were 158 out of 185 consisting of $85.4 \%$ of the overall sample, while female respondents were 27 consisting of $14.6 \%$ of the overall sample. In this case, main portion of respondents is male which indicates that more men are represented in the NRSP MFBL.

Table 1. Demographic Analysis

\begin{tabular}{|c|c|c|c|c|c|}
\hline & & Frequence & Percent & Percent Validation & Amount Percent \\
\hline \multirow{4}{*}{ Age } & $20-30$ & 85 & 45.9 & 45.9 & 45.9 \\
\hline & $30-40$ & 84 & 45.4 & 45.4 & 91.4 \\
\hline & $40-50$ & 10 & 5,4 & 5,4 & 96,8 \\
\hline & 50-up & 6 & 3.2 & 3.2 & 100 \\
\hline \multirow{2}{*}{ Gender } & Male & 158 & 85,4 & 85,4 & 85,4 \\
\hline & Female & 27 & 14.6 & 14.6 & 100 \\
\hline \multirow{3}{*}{ Qualification } & Bachelor & 64 & 34.6 & 34.6 & 34.6 \\
\hline & Master & 111 & 60 & 60 & 94.6 \\
\hline & MS / Mphil & 10 & 5,4 & 5,4 & 100 \\
\hline \multirow{2}{*}{ Experience } & Less than 1 year & 62 & 33.5 & 33.5 & 33.5 \\
\hline & $1-5$ & 123 & 66,5 & 66,5 & 100 \\
\hline
\end{tabular}

Second, for the age classification of respondents, four different scales ranging from $20-30,30-40,40-50$ and 50 and above were taken. The first scale is the age classification of 85 respondents with a composition of 45.9 percent, the second scale is 84 respondents with a composition of 45.4 percent, the third scale is 10 respondents with a composition of 5.4 percent and the fourth scale is 6 respondents with a sample size of 3.2 percent. In terms of age, the main strengths of respondents are on a scale of 20-30 and 30-40.

For qualification, four categories have been taken, namely Bachelor, Master, MS/MPhil and PHD. Single respondents were 64 respondents as much as 34.6 percent, master 111 as much as 60 percent and MS / M-Phil 10 respondents who made up 5.4 percent of the total sample. For experience, four categories have been arranged, namely less than one year, 1-5, 6-10 and 11 or more. 62 respondents from category I with a sample size of 33.5 percent, category II as many as 123 respondents with a sample size of 66.5 percent.

Table 2. Descriptive Statistics

\begin{tabular}{cccccccr}
\hline Variable & N & Min & Max & Mean & Std.Dev & Skewness & kurtosis \\
\hline HIWP's & 185 & 1.44 & 4.44 & 3.3327 & 0.82121 & -.690 & -.635 \\
EE & 185 & 1.71 & 4.57 & 3.2973 & 0.81358 & -.325 & -1.261 \\
JS & 185 & 1.50 & 4.36 & 3.2602 & 0.64252 & -.512 & -.519 \\
\hline
\end{tabular}

Table 2 shows the results for the three variables. All respondents remain valid and to the point. The average HIWP score is 3.3327 and the minimum value gets 1.44 and the 
maximum value gets 4.44. The standard deviation for HIWP shows 0.82121 . The mean value for EE has score 3.2973, and the minimum value has score 1.71, while the maximum value has score 4.57. The standard deviation for EE shows 0.81358 , while the mean value for JS shows 3.2602, and the minimum value shows 1.50 ,also the maximum value shows 4.36. The standard deviation for JS gets 0.64252 as the score.

In the literature on human resource management and organizational behavior, employee engagement is undoubtedly an interesting and critical construct. Its main effort is to explore important gaps in the literature on employee engagement construction, in terms of crosssectional research, revealing gaps as defined above. Regarding the gaps identified above can be classified as theoretical gaps and empirical gaps (Marzuki, 2017).

Table 3. Reliability Test

\begin{tabular}{ccc}
\hline Variable & Alpha Cronbach & Item \\
\hline HIWP's & 0.807 & 9 \\
EE & 0.711 & 7 \\
JS & 0.738 & 14 \\
\hline
\end{tabular}

There are differences in Cronbach's alpha values for various variables used in this study. Cronbach's alpha shows the consistency of the respondents' responses. The conclusion on this basis is that the instrument is reliable. The Cronbach alpha value for HIWP is 0.807 . Employee engagement received 0.711 Cronbach's alpha while job satisfaction was 0.738 . These values indicate instrument consistency and instrument reliability. The impact of leadership, work orientation, and workplace structure on employee performance is that leadership, work orientation and culture greatly influence employee performance simultaneously on employees, leadership seems to get a positive and significant impact on employee performance, leadership is second strongest variable that affects performance in this study, work orientation seems to get a positive and significant impact on employee performance, work orientation is a strongest variable that has an impact on performance, workplace structure seems to has a negative and insignificant impact on employee performance (Maabuat, 2016).

Table 4. Correlation

\begin{tabular}{cccc}
\hline & HIWP's & EE & JS \\
\hline HIWP's & 1 & & \\
EE & 0,294 & 1 & \\
JS & 0,728 & 0,597 & 1 \\
\hline
\end{tabular}

Correlation test is conducted to test whether two variables are linearly related in several populations. Correlation basically tells about the intensity (strong or weak) of the relationship between two variables and the direction of the relationship (positive or negative). Table 4 shows about the correlation between different variables. The first correlation is between HIWP's and employee engagement and this correlation value is 0.294 which indicates a moderate level of correlation between the two variables. The second correlation between HIWP and job satisfaction is 0.728 which indicates a moderate correlation between the two variables and presents a strong relationship between the two variables. Meanwhile, 
third correlation between employee engagement and work satisfaction shows 0.597 which indicates a moderate correlation and a strong relationship between the two variables.

According to (Marzuki, 2017), in the literature on human resource management and organizational behavior, employee engagement is undoubtedly an interesting and critical construct. Its main effort is to explore important gaps in the literature on employee engagement construction, in terms of cross-sectional research, revealing gaps as defined above. Regarding the gaps identified above can be classified as theoretical gaps and empirical gaps.

Table 5. Empirical Result for Hypothesis 1

\begin{tabular}{ccccc}
\hline Model & B & Std.Error & T & Sig \\
\hline Constant & 2.327 & 0.240 & 9.686 & 0.0000 \\
HIWP's & 0.291 & 0.070 & 4.159 & 0.0000 \\
\hline
\end{tabular}

$\mathrm{N}=185, \mathrm{R}=0.294, \mathrm{R}$ Square $=0.086, \mathrm{~F}=17.299$

a. Variabel terikat: EE

b. Predictor: HIWP's

To analyze the connection between the independent variable and the dependent variable, a regression test could be performed. This test tells about the dependence of the dependent variable on the independent variable which shows that how much change in the dependent variable may be caused by the independent variable. In this test, the dependent variable is employee engagement and the independent variable is HIWP. Based on the test, the R-Square value is 0.086 , which indicates that 8 percent of changes in the dependent variable are caused by the independent variable. The $t$ and $F$ values are greater than 2 and 5, respectively, which indicates the suitability of the overall model. So the conclusion is about the null hypothesis is rejected based on the statistical support provided by this regression which shows a very significant relationship between the two variables.

Table 6. Empirical Result with Hypothesis 2

\begin{tabular}{ccccc}
\hline Model & B & Std.Error & T & Sig \\
\hline Constant & 1,361 & 0,136 & 10,007 & 0,0000 \\
HIWP ini & 0.570 & 0,040 & 14,379 & 0,0000 \\
\hline
\end{tabular}

$\mathrm{N}=185, \mathrm{R}=0,728, \mathrm{R}$ Square $=0,530, \mathrm{~F}=206,753$

a. Variabel Terikat: JS

b. Predictor: HIWP's

To analyze the connection between the independent variable and the dependent variable, a regression test could be performed. This test tells about the dependence of the dependent variable on the independent variable which shows that how much change in the dependent variable may be caused by the independent variable. Test here, work satisfaction as the dependent variable and the independent variable is HIWP. Based on the test, it was obtained that the R-Square value was 0.530 , which indicates that 53 percent of changes in the dependent variable were caused by the independent variable. The $t$ and $F$ values are respectively greater than 2 and 5. So the conclusion is that the null hypothesis is rejected based on the statistical support provided by this regression which shows a very significant relationship between the two variables. 
Table 7. Model Summary

\begin{tabular}{cccccc}
\hline $\mathbf{R}$ & $\mathbf{R}-$ Square & $\mathbf{F}$ & df1 & df2 & hal \\
\hline 0.8312 & 0,6909 & 203.4009 & 2.0000 & 182.0000 & 0.0000 \\
\hline
\end{tabular}

Here the $\mathrm{N}$ value is 185 and the indirect effect is 9 percent which indicates that the mediation effect is 9 percent and with the beta coefficient value of employee engagement and high-involvement work practices of 33 percent and 47 percent, the T value is 9 and 14, respectively. the $\mathrm{F}$ value of 203 and the value of 0.0000 which indicate a mediating effect.

Here, in this mediation effect table, the R-Square value is 0.6909 which indicates that there is a strong influence of the mediator between the dependent variable and the independent variable by 69 percent. High $\mathrm{F}$ values and above 5 indicate that the overall model is fit. The significance level value is 0.0000 which indicates the high significance of the connection between variables. $T$ value of all variables is greater than 2 which indicates that the variable is suitable for individual testing.

Table 8. Model

\begin{tabular}{ccccccc}
\hline & coeficien & Se & T & $\mathbf{p}$ & LLCl & ULCl \\
\hline Konstanta & 0,5910 & 0.1361 & 4.3423 & 0.0000 & 0,3224 & 0.8595 \\
EE & 0,3309 & 0,0341 & 9.7190 & 0.0000 & 0.2637 & 0,3981 \\
HIWP & 0.4735 & 0,0337 & 14,0365 & 0.0000 & 0.4069 & 0,5401 \\
\hline
\end{tabular}

$\mathrm{N}=185$ Indirect Effect $=0,0964$

Here the $\mathrm{N}$ value is 185 and the indirect effect is 9 percent which indicates that the mediation effect is 9 percent and with the beta coefficient value of employee engagement and high-involvement work practices of 33 percent and 47 percent, the T value is 9 and 14, respectively. the $\mathrm{F}$ value of 203 and the value of 0.0000 which indicate a mediating effect.

Table 9. Model Summary

\begin{tabular}{cccccc}
\hline $\mathbf{R}$ & R-Square & $\mathbf{F}$ & $\mathbf{d f 1}$ & $\mathbf{d f 2}$ & hal \\
\hline 0.8312 & 0,6909 & 203.4009 & 2.0000 & 182.0000 & 0.0000 \\
\hline
\end{tabular}

Here, in this mediation effect table, the R-Square value is 0.6909 which indicates that there is a strong influence of the mediator between the dependent variable and the independent variable by 69 percent. High F values and above 5 indicate that the overall model is fit. The significance level value is 0.0000 which indicates the high significance of the connection between variables. The $T$ value for all variables is greater than 2 which indicates that the variable is suitable for individual testing.

Table 10. Model

\begin{tabular}{ccccccc}
\hline & Coefficient & Se & $\mathbf{t}$ & $\mathbf{p}$ & LLCl & ULCl \\
\hline Constant & 0,5910 & 0.1361 & 4.3423 & 0.0000 & 0,3224 & 0.8595 \\
EE & 0,3309 & 0,0341 & 9.7190 & 0.0000 & 0.2637 & 0,3981 \\
HIWP & 0.4735 & 0,0337 & 14,0365 & 0.0000 & 0.4069 & 0,5401 \\
\hline
\end{tabular}

$\mathrm{N}=185$ Indirect Effect $=0,0964$ 
The researcher used Andrew F Hayes to interpret the results, which inferred the mediating variables. First, the direct influence of the independent variable on the dependent variable is examined and investigated, then the indirect impact of the independent variable on the dependent variable. Here the $\mathrm{T}$ value gets a higher than 2 which indicates the need for this mediating variable in obtaining the results and the connection between the independent variable and the dependent variable.

Table 11. Direct Effect of X on Y (HIWP's on JS)

\begin{tabular}{cccccc}
\hline Effect & SE & T & Sig & LLCl & ULCI \\
\hline 0.4735 & 0.0337 & 14.0365 & 0.0000 & 0.4069 & 0.5401 \\
\hline
\end{tabular}

Here, researchers run different SPSS and Andrew, F. Hayes tests to analyze the connection between the independent variable, HIWP and the dependent variable, job satisfaction with a mediator, employee engagement. In the first step, the researcher conducted a reliability test to analyze the different Cronbach's alpha values for the three variables. Of all Cronbach's reliable alpha, it can be seen that the three instrument variables are reliable for measurement. The Cronbach alpha for the independent variable, HIWP is 0.807. Cronbach's alpha value for the mediator, employee engagement is 0.711 and the dependent variable is job satisfaction 0.738 .

Table 12. Indirect Effect of X on Y (HIWP's in JS)

\begin{tabular}{ccccc}
\hline & Efect & Boot SE & Boot LLCl & Boot ULCI \\
\hline EE & 0,0964 & 0,0239 & 0,0527 & 0,1477 \\
\hline
\end{tabular}

Likewise, the three HIWP's variables, employee engagement and job satisfaction are correlated with each other. The first correlation is between HIWP's and employee engagement and this correlation value is 0.294 which indicates a high correlation between the two variables. The second correlation between HIWP and work satisfaction is 0.728 which indicates a high correlation between the two variables and implies a strong connection between the two variables. Then, third connection between employee engagement and job satisfaction of 0.597 indicates a high correlation and a strong relationship between the two variables.

Table 13. Summary of Hypothesis Testing

\begin{tabular}{|c|c|c|}
\hline Hypothesis & Statement & Result \\
\hline 1 & There is a positive effect of high involvement work practices on job satisfaction. & accepted \\
\hline 2 & There is a positive influence on employee engagement on job satisfaction. & accepted \\
\hline 3 & There is a positive effect of high engagement work practices on employee engagement. & accepted \\
\hline 4 & $\begin{array}{l}\text { There is a positive and significant influence between high involvement work practices } \\
\text { on job satisfaction with the mediating role of employee involvement }\end{array}$ & accepted \\
\hline
\end{tabular}

Researchers run a regression analysis to analyze the connection between the dependent variable and the independent variable. A regression test shows dependence of the dependent variable on the independent variable, which is a clear and understandable indication that how much change in the dependent variable may be caused by the independent variable. 
Here the dependent variable is work satisfaction and the independent variable is HIWP. Based on the test, it was obtained that the R-Square value was 0.530, which indicates that 53 percent of changes in the dependent variable were caused by the independent variable. The $t$ and $F$ values are respectively greater than 2 and 5 . So the conclusion is that the null hypothesis is rejected based on the statistical support provided by this regression which shows a very significant relationship between the two variables.

Furthermore, regression is conducted to analyze the connection between the independent variable and the mediating variable. Here the independent variable is HIWP and the dependent variable is employee engagement. Based on the test, the R-Square value is 0.086 , which indicates that 8 percent of changes in the dependent variable are caused by the independent variable. The $\mathrm{T}$ and $\mathrm{F}$ values are greater than 2 and 5 , respectively, which indicates the suitability of the overall model. So the conclusion is about the null hypothesis is rejected based on the statistical support provided by this regression which shows a very significant relationship between the two variables.

Finally, to examine correlation between the mediating variable, employee engagement and the dependent variable on job satisfaction, the researcher conducted a regression analysis. In this test, the dependent variable is job satisfaction and the independent variable is employee engagement. Based on the test, the R-Square value is 0.356 which indicates that almost 36 percent of changes in the dependent variable are caused by the independent variable. The $\mathrm{T}$ and $\mathrm{F}$ values are greater than 2 and 5 , respectively, which indicates the suitability of the overall model. So the conclusion is that the null hypothesis is rejected based on the statistical support provided by this regression which shows a very significant relationship between the two variables.

To test the direct and indirect impacts on the dependent variable. First, the direct impactt of the independent variable on the dependent variable is examined and analyzed, then the indirect impact of the independent variable on the dependent variable. Here the $T$ value gets higher than 2 which indicates the need for this mediating variable in obtaining the results and connection between the independent variable and the dependent variable. The R-Square value gets score 0.6909 which indicates that there is a strong influence of the mediator between the dependent variable and the independent variable by 69 percent. Significance level value is 0.0000 which indicates the high significance of the relationship between variables.

This present study was purposed to investigate the impact of HIWP on work satisfaction and how the part of HIWP through employee engagement that in turn leads to work satisfaction and increase knowledge of the factors that cause job satisfaction to increase. level or lower level. Second, this study is adding value to the HIWP literature, existing employee engagement and worl satisfaction. Third, it fulfillsacademic research requirements of the researcher.

Important factors affecting job satisfaction are discussed. These factors can help increase job satisfaction. HIWP, which includes power, information, rewards and knowledge, helps increase job satisfaction. In this study, researchers also found that the relationship between HIWP and job satisfaction was high. This shows that HIWP plays an important role in increasing job satisfaction for employees (Iddagoda \& Opatha, 2017). This HIWP positively affects job satisfaction in the context of a direct relationship, as supported by the literature. Job satisfaction is an outcome measure as believed by many authors and researchers which 
further have an essential part in evaluating the performance of an employee. An employee performance is closely related to job satisfaction.

As part of HIWP, power impacts representative engagement in a positive or negative way. Representatives should be given a feeling of self-sufficiency, relating to the 'flexibility, freedom, and caution' given the representatives to plan their own specific work and deciding on the most ideal approach to completing their tasks (Crawford et al., 2014). According to the results, it is possible that authority could push representation to become more locked in.

The second segment, namely information, also affects employee engagement, both empathetically and negatively. Provides representatives with data on issues affecting their work, empowering heads and associations to be more direct, which is important because it 'helps representatives find connections between their activities and company operations, along these lines enhancing the psychological part of engagement (Iddagoda \& Opatha, 2017). Managers should strive to create stable and reliable relationships with their representatives by using open correspondence and showing them a sense of consideration (Marzuki, 2017). Also, engagement might be achieved since individuals know a direct relationship between their activities and the hierarchical outcome (Macey et al., 2011).

The third segment of HIWP, namely reward also has an impact on worker engagement and this impact or effect can be both positive or negative. As indicated by (Iddagoda \& Opatha, 2017), managers must offer representatives with advantages and assets 'which would obligate them to respond in a similar way with a greater number of engagements'. Crawford et al. (2014) also found that gifts and recognition were totally identified with engagement. Rachmawati (2014) found that both natural and external remuneration were fundamentally linked to engagement. Resultspresent sufficient proof to indicate that the act of compensating workers for their execution seems to be essential to expand their involvement.

The fourth section of knowledge has a noteworthy effect on worker engagement thereby increasing it to a higher or lower level, it is also argued that an increase in professions and work preparation activities that are specifically coordinated towards self-improvement and the advancement of authoritative individuals can influence their level of engagement. Shuck et al. (2014) ponder and assume that honing representatives' interest in HRD -, for example, training programs, administrative improvement activities, and learning opportunities - is essentially identified by their subjective, behavioral, and passionate engagement. Ho et al. (2014) also found that more important learning about open doors for workers influenced their engagement. Resultsdirectly show that an association's interest in enhancing individuals' information, talents and capacities can fundamentally influence their level of engagement. Studies and research results also show that there is a significant connection between employee engagement and job satisfaction. Employee engagement can have a positive influence on work satisfaction if employee engagement is focused on the organization from an employee perspective. A common consensus has developed whether employee engagement provides anything unique in combining motivation and engagement with behavior (Ho et al., 2014). It has also been studied that the idea of employee engagement integrates features with many other work-related behaviors, including work satisfaction, job participation, and perceived organizational support.

Finally, this study concludes that mediation is necessary for the connection between HIWP and work satisfaction. Researchers have tested either analyzed the need for a mediator, employee engagement. It has been tested and shown in the regression that there 
is a positive relationship between employee engagement and work satisfaction,also there is a mediation relationship. So that employee engagement performs as a mediator between HIWP and work satisfaction and it is also supported in the literature.

\section{CONCLUSION}

Our findings suggest that if proper implementation of high engagement practices is carried out then this will lead to positive results along with employee engagement and further to job satisfaction. A relationship between high-involvement work practices and employee engagement is positively correlated with each other and that has been proven and demonstrated by researchers in the regression segment of these two variables. Another major finding of this study is that mediation is required for connectionbetween high-involvement work practices and job satisfaction. In this study, it is confirmed that job satisfaction is one of the important issues in evaluating organizational performance. Because employees are the core asset of every organization and the output or productivity of the organization is made by the employees of the organization. So if the employee is satisfied then he will be more productive and not involved in any counterproductive activities, the organization will be productive. Job satisfaction is defined and explained that whether an employee feels satisfied with his job then she may contribute effectively to organizational growth.

Job satisfaction of an employee can be stimulated and very productive if highinvolvement work practices are implemented properly. And if employees are committed, engaged and satisfied with their work and there is proper support for them from supervisors or management then they will be more productive and this will lead to organizational production. Because employee job satisfaction is a major problem for all organizations, what researchers feel is necessary to address work practices that involve high involvement with job satisfaction. This study is useful for people who want to run their own service business, because employees are the main source of profit and they are the core asset of any organization and if employees are dissatisfied with their work and work then they may not be able to perform well and they may not be productive in their work. their jobs and jobs.

The model represents the following hypothesis which shows a positive relationship between HIWP and work satisfaction. According to the results and findings, the first managerial implication is that they should address and eliminate the factors that cause decreased work satisfaction between employees in an organization. By eliminating the factors that cause a decrease in job satisfaction, it will help managers and employees to improve their performance. Likewise, managers must focus on improving HIWP components, namely power, knowledge, reward and information and employee engagement as well as to increase job satisfaction among employees for better performance and ultimately for better organizational growth.

What is new from this research is that empirical testing has been carried out to investigate the connection between HIWP and work satisfaction with employee engagement as mediating role. So in this sense, it is a small attempt to contribute to the existing literature on the core variables of this study and to open new avenues of data and findings for research workers to analyze the influence of HIWP in an organization on employment. satisfaction. And it helps research workers to conduct further studies and discussions on the importance of these greatparticipation work performance, also to examine a strong impact of these performances on job satisfaction among employees to further improve organizational performance. 


\section{REFERENCES}

BinBakr, M. B., \& Ahmed, E. I. (2019). High-Involvement Work Processes and Organizational Commitment of Female Faculty in Saudi Arabia. International Journal of Leadership in Education, 22(5), 597-616. https://doi.org/10.1080/13603124 .2018.1529819.

Christian, M. S., Garza, A. S., \& Slaughter, J. E. (2011). Work Engagement: A Quantitative Review and Test of Its Relations with Task and Contextual Performance. Personnel Psychology, 64(1), 89-136.

Crawford, E. R., Rich, B. L., Buckman, B., \& Bergeron, J. (2014). Employee Engagement in Theory and Practice. New York, NY: Routledge.

Emmywati, E., Sukatmadiredja, N. R., \& Wibowo, B. S. (2020). Job Crafting, Work Engagement and Sustainable for Employee Performance in Directorate of Telecommunications Directorat General of Postal and Informatics Implementation in Jakarta. Media Mahardhika, 18(2), 179-191.

Ho, A. S., Sarti, E. E., Jain, K. S., Wang, H., Nixon, I. J., Shaha, A. R., Shah, J. P., Kraus, D. H., Ghossein, R., \& Fish, S. A. (2014). Malignancy Rate in Thyroid Nodules Classified as Bethesda Category III (AUS/FLUS). Thyroid, 24(5), 832-839.

Iddagoda, Y. A., \& Opatha, H. (2017). Identified Research Gaps in Employee Engagement. International Business Research, 10(2), 63-73.

Lowe Jr, J. M. (2021). One Team, One Fight: the Role of Empowerment in the US Navy. (Unpublished Thesis). Trident University International.

Maabuat, E. S. (2016). Pengaruh Kepemimpinan, Orientasi Kerja, dan Budaya Organisasi terhadap Kinerja Pegawai (Studi Pada Dispenda Sulut UPTD Tondano). Jurnal Berkala Ilmiah Efisiensi, 16(1), 31-40.

Macey, W. H., Schneider, B., Barbera, K. M., \& Young, S. A. (2011). Employee Engagement: Tools for Analysis, Practice, and Competitive Advantage. New Jersey: John Wiley \& Sons.

Marzuki, M. (2017). Employee Engagement Cross-Sectional Model dan Implikasinya pada Kinerja. Jurnal Visioner \& Strategis, 6(2), 77-88.

Rachmawati, M. (2014). Employee Engagement Sebagai Kunci Meningkatkan Kinerja Karyawan (International Journal Review). Among Makarti, 6(2), 52-65. https://doi.org/10.52353/ ama.v6i2.88.

Salanova, M., Schaufeli, W., Martínez, I., \& Bresó, E. (2010). How Obstacles and Facilitators Predict Academic Performance: The Mediating Role of Study Burnout and Engagement. Anxiety, Stress \& Coping, 23(1), 53-70.

Shuck, B., Twyford, D., Reio Jr, T. G., \& Shuck, A. (2014). Human Resource Development Practices and Employee Engagement: Examining The Connection with Employee Turnover Intentions. Human Resource Development Quarterly, 25(2), 239-270.

Tahir, R. (2013). Keterikatan Karyawan dan Kontribusinya dalam Meningkatkan Kinerja Perusahaan. Jurnal Ilmu Manajemen Dan Bisnis, 4(1), 1-11.

Ulum, I. (2012). Investigasi Hubungan antara Kinerja Modal Intelektual dan Praktik Pengungkapannya dalam Laporan Tahunan Perusahaan. Jurnal Ekonomi Bisnis, 17(1), 36-45. 